\title{
Migrant Crossing Borders: Bridging Cultural Difference and Securing a Third Space in the Host Country
}

\author{
Tri Murniati
}

Fakultas Ilmu Budaya, Universitas Jenderal Soedirman

tri.murniati@unsoed.ac.id

DOI: $10.20884 / 1 . j 1 i .2020 .11 .1 .2168$

\begin{abstract}
Article History: ABSTRACT
First Received:

$05 / 12 / 2019$

Being migrant workers means being ready to face and accept the challenge of

Final Revision: cultural differences in the host country. Bridging in two different cultures, this involves adaptation. However, the process of adaptation-welcoming,

$29 / 04 / 2020$ embracing and finally accepting - to the host country's culture is not easy. Tearing between the two different worlds, their migrant experience can be torturous. These migrants are not only transitioning into a new life in the host

Available online: country but also translating a new culture in their new life phase. Such experiences, then, open up a space-an interstice - which enables these

$25 / 06 / 2020$ migrants to survive in the new life, the migrant life. Taking, observing, and interpreting the stories of the Indonesian domestic workers (IDWs) in Hong Kong, I argue that these women are able to not only translate but also adopt the new culture of the host country through assimilation, acculturation and the invention of a common ground, a third space in which they are able to feel like home in the host country. In addition, the process of acculturation involves negotiation which allows IDWs to find a middle ground between two different cultures and the third space illustrates their adjustment in bridging and crossing the cultural border between the home and the host countries. Between Indonesia and Hong Kong, Victoria Park arises as a comfort space which can ease the pain of being stranger in Hong Kong.
\end{abstract}

Keywords: Adaptation; cultural difference; indonesian domestic workers; migrant experience; third space

\section{INTRODUCTION}

Being migrant workers means being ready to face and accept the challenge of cultural differences in the host country. The Indonesian female migrant workers in Hong Kong who work as domestic workers, for example, are exposed to their employers' culture. The cultural differences between the home and host countries, in a way, have built a boundary, which affects the lives of the migrant workers. This is clearly illustrated in their written narratives, for example Bayu Insani's and Ida Raihan's memoir titled TKW Menulis (Indonesian Domestic Workers Write). In their memoir, Insani and Raihan show that some of them are able to adapt and even adopt the new culture of the host country, while some may not. As illustrated in their stories, those who are able to adapt have shown a tremendous effort to bridge the cultural boundaries 
between their homeland and the host land. However, the process of adaptation-welcoming, embracing and finally accepting - to the host country's culture is not easy. Tearing between the two different worlds, their migrant experience can be torturous. These migrants are not only transitioning into a new life in the host country but also translating a new culture in their new life phase. Homi Bhabha once notes how "this liminality of migrant experience is no less a transitional phenomenon than a translational one" (321). This means when transitioning into their new life in the host country, migrants simultaneously translate the new culture. This indicates the process of cultural interaction, the meeting of two different cultures.

Such experiences, then, open up a space - an interstice - which enables these migrants to survive in the new life, the migrant life. Taking, observing, and interpreting the stories of the Indonesian domestic workers (IDWs) in Hong Kong, I argue that these women are able to not only translate but also adopt the new culture of the host country through assimilation, acculturation and the invention of a common ground, a third space in which they are able to feel like home in the host country. In addition, the process of acculturation involves negotiation which allows IDWs to find a middle ground between two different cultures and the third space illustrates their adjustment in bridging and crossing the cultural border between the home and the host countries. Victoria Park in Hong Kong, I argue, clearly embodies the third space that facilitates the Indonesian migrant workers to have a room to breathe and enjoy a little 'taste of home.'

In exploring the negotiations and the third space of IDWs' migratory experiences, I utilize a memoir written by two IDWs namely Bayu Insani and Ida Raihan, titled TKW Menulis (IDWs Write). Written in Indonesian, this memoir, which was published in 2011, vividly illustrates Insani's and Raihan's migrant journey in Hong Kong. To make an effective discussion, I divide this article into three sections: the first section provides general information on migrants' adjustment in the host country; the second section offers an overview of the IDWs in Hong Kong and Bayu Insani and Ida Raihan's migrant experiences in particular including their efforts in negotiating and adjusting life in the host country; and the last part focuses on explicating Victoria Park, which emerges as the interstice for IDWs' life in Hong Kong.

\section{Migrants' Adjustment in the Host Countries}

Embarking on a journey to in the hope of finding a better life, many people cross borders to work in foreign countries. Working overseas means preparing oneself to a new different culture and environment. In addition, being exposed to the host country culture, migrants are open to 
cultural interaction. This process of cultural interaction can be in the form of assimilation or acculturation which include negotiations where migrants are trying to adjust to the majority culture which is their employer's culture. In terms of acculturation, Christian L. van Tonder and Werner Soontiens in their article "Migrant Acculturation and the Workplace" quoting Berry (2001), define acculturation as "to the process of psychological change in a person (the migrant) resulting from contact and involvement with representatives of other cultures (usually and typically the host country culture)... entails relinquishing elements of the person's culture of origin ('culture shedding') and adopting and internalizing elements of the host country culture ('culture learning')" (1041). van Tonder and Soontiens highlight the cultural interaction between two different cultures of the home and the host countries. This particular process inevitably involves one to give up the old culture and co-opt the new culture. In the case of foreign domestic helpers, they may adopt certain values of the host countries and leave behind certain values of their home country. van Tonder and Soontiens further explicate that migrant acculturation as the "consequence of social encounters through which migrant integration and absorption into the (host) community is 'achieved', occurs when the migrant, for example, participates in sport, religious and/or other community-based activities" (1041). This also means complying to the shared values operated within the community of the host country.

Related to the issue of cultural interaction, A. Milostivaya et al. argue that it is prominently echoed in "migrant literature created in a so-called "third space"(181). This notion of a third space is coined by Homi K. Bhaba. Further Milostivaya et al. explicate that this theory is "based on the existence of such space where cultural borders open up to each other, and creation of a new hybrid culture that combines their features and atones their differences" (Milostivaya et al. 181). Third space illustrates a third culture bridging the old and the new. A new hyphened identity leaves migrant with a new culture, the migrant culture.

\section{RESULT \& DISCUSSION}

\section{IDWs in Hong Kong and the Cultural Border: Bridging and Negotiating Cultural Differences}

The presence of Indonesian migrant workers in Hong Kong dated back in wave of migration in the 90s. People were excited to work abroad because those who did first and returned have shown a tremendous change in terms of economic betterment seen from improvements in housing and other household goods including vehicles such as motorcycles and cars1. This fact supports the reason why many Indonesians jump onto the bandwagon to be a

\footnotetext{
${ }^{1}$ The remittance is spent to buy non-productive goods such as the aforementioned (Adi cited in Wulan 2010)
} 
migrant worker. Besides, the scarcity and unavailability of jobs at that time, encourage people to seek work abroad.

In 2015, around 3,837 million Indonesian migrant workers are noted to work in more than 40 countries ranging from Asia (including South East Asia), Australia and Oceania, the Middle East, Africa, the United States, and Europe (Bappenas 2015). For Hong Kong itself, 167.000 of Indonesian migrant workers have worked in this ex-British colony. In Hong Kong, most of the Indonesian migrant workers work as domestic helpers and nannies. There are some reasons why Indonesians especially women, are eager to work in Hong Kong. First, Hong Kong offers a relatively higher wage than other destination countries such as Malaysia and Saudi Arabia. Second, Hong Kong government has a clear and strict rules and regulation concerning foreign migrant workers. Hong Kong, in particular, applies "three main regulating bodies that form the legislative framework for Female Domestic Helpers (FDHs)" namely the Employment Ordinance, the Immigration Ordinance, and the Employers Retraining Ordinance” (Mok 105-6). This ensures foreign migrant workers in Hong Kong to have a legal protection.

However, in practice, not all employers comply the rules and regulations made. In some cases, some of them even violate those rules and regulations. As a result, many migrant workers have to face and endure "many challenges relating to decent work, including timely payment of wages, physical, verbal and emotional abuse from their employers, and detention" (Indonesia: Decent Work). More to this, these migrant workers, for instance, are often in the position of being unable to fight back or refuse employers' request and command. Such problems are clearly portrayed in Insani's and Raihan's memoir, even though they do not personally experience a bad case such as abuses or termination.

As migrant domestic helper, IDWs' main duty is to do house chores and it is common to note that most employers will always demand that this is well taken care of. The memoir clearly describes the common characteristics of the employers such as strict, demanding, and discipline. Different power relation between the employers and the migrant domestic workers also affects how these workers perceive themselves and others, which is intertwined with the identity previously shaped. In Indonesia, for example, domestic helpers suffer from negative stereotyping. They are mostly described as nothing but physical workers who have to operate for a meager salary, in often bad conditions. In addition, in the host country, Hong Kong, these women still have to face the fact that some employers have similar perception and consider IDWs as merely physical workers. Such a situation situates IDWs at risk of injustice treatments which can lead to a contract violation, for example. This leaves the migrant workers as the one 
who suffers. Insani, who has experience this, briefly narrates "....in the letter contract I only served one household, but when I arrived at my employer's house, I actually had to work in two houses. I recalled my agent's caution that I should obey my employer. I felt helpless" (Insani and Raihan 15). Insani's story exemplifies a case where employer violates the contract. This condition is exacerbated by the fact that the agents oftentimes stand by the employers. As a result, the migrant workers themselves are getting more marginalized. They are conditioned to rely on themselves.

Likewise, Raihan also underwent the same situation where she could not help herself other than to listen to and obey her employers' command. In addition, as a new worker, this literally means that Raihan is on her probation period. She illustrates her disadvantaged position as follow: "Working under supervision was not easy because it made me uncomfortable. However, I could not anything since I could be terminated. No matter how bad it was, as a domestic worker, we would remain silent" (Insani and Raihan 134). In order to survive the job, IDWs have to negotiate things with themselves, for example, living under the same roof with their employers with all the complexities including overcoming challenges caused by the abstract borders such as the strong imbalanced power relation between the employer and the employee.

Both Insani and Raihan's experiences imply the impressions that migrant domestic workers are inclined to be submissive, particularly because of the fact that they are 'new.' By 'new,' it refers to several situations such as these women are literally new to both their jobs and the host country, which includes living in their employer's residence. Nonetheless, as time goes by, Insani and Raihan start to gain power and trust. This means they are also able to negotiate their positions in. The period when IDWs start to adjust to the new culture is very crucial because it affects much on how well the relationship between them and their employers will be. During this period, Insani and Raihan as other domestic workers are struggling to regulate their new lives. Insani confesses how her first week was hard on one hand. On the other hand, she learns a lot how things work in that house. However, she still has another problem, the language problem (Insani and Raihan 18). For those who work in Hong Kong, mastering Cantonese, for example, is a must since it is the main language used. Failed to learn Cantonese, in some cases, can result in misunderstanding between the employer and the worker because they cannot communicate well. This means communication breakdowns are likely to occur as the receiver could not comprehend the messages sent by the sender. In a worst-case scenario, such a misunderstanding can lead to conflicts between the employer and employee and it is also possible that work termination might occur. This linguistic tension turns to impact the communication built between the employer and employee. Observing the importance to acquire host country language and its impact to foreign 
migrant workers, Raihan concludes that building a good communication with employers is one of the biggest problems faced by most domestic workers, in this case the Indonesian domestic workers. Cases happened, apparently are caused by miscommunication and it can cause a unilateral termination (Insani and Raihan 127). This is because the employer has the power to terminate their employees if their work performance is not satisfying.

The challenges faced by the domestic workers are not only to do physical works or to master the host country language, but also to adjust themselves to their host country/employers' culture. One simple example is how to learn a new value in the host country which is different from the one in the home country. Insani has her own story on learning new values in the Hong Kong that is learning how to value time better. In Hong Kong, Insani finds out that people are very concern about time. She observes how people always walk in a hurry as if they do not want to waste time; for them time is precious. Compared to her homeland's experience, Indonesians value time differently (Insani and Raihan 25). This different time perception, somehow, bothers her, and Insani finally takes a lesson not to waste time. She herself has to negotiate her time to do prayer during working hours. Since her employer considers her praying ritual as a waste of time, Insani has to explain and convince her employers that the ritual will not affect her works since it only takes a couple minutes to do it. She admits that her employers agree on one condition, that the prayers will not bother her work performance (Insani and Raihan 25). Here, Insani has shown the readers that migrant domestic workers learn cultural differences in one hand and try to negotiate her [disadvantaged] position on the other hand. The win-win solution, as seen in Insani's case, appears to signify a good cooperation between domestic workers and the employers. However, this is to say that every cultural difference can be bridged, or a win-win solution can be met because it also depends on how good the communication between the employers and the employees.

Similar learning is also acquired by Raihan. As she often sees how people in Hong Kong obey the traffic rules when they are on the street, for example, when they cross the street, Raihan realized that discipline, in this case, by complying the rules and regulations is needed to create a good street condition which benefits all street users. Similar to Insani, Raihan inevitably compares how Indonesians and Hong Kong residents behave on the street and she can see that they are totally different when it comes to complying rule and regulations. An insight gained, according to Raihan, is that people should start from their own personal being to learn to be better. In her memoir, she exemplifies the attitude to minimalize littering (132-3). Comparing and contrasting habits in both countries provide these domestic workers a room to value what is 
best for them. Conforming better habits also illustrate the process of embracing and accepting host country's cultures. Raihan and Insani's experiences illustrate well what van Tonder and Soontiens point out as migrant's process of acculturation. On the other side of the spectrum, some employers happen to violate government rules and regulations concerning foreign migrant workers where the workers the one who lose and victimized.

Nonetheless, throughout Raihan and Insani's memoirs, readers can learn how these migrant domestic workers are considered successful adjusting in their new lives. They do face challenges, but they are able to manage them somehow. These women have successfully acquired a 'safe space' in their employers' residence. In a bigger scale, IDWs in Hong Kong has also benefitted from a public place called Victoria Park. In this particular park, they are able to secure it as a comfort zone every single week on Sunday-which is their day off - to ease the feeling of estrangement of living in a foreign country.

\section{IDWs and the Invention of a Third Space: Treasuring a 'Taste of Home' in Victoria Park}

As required by the Hong Kong government, all employers obligate to provide a day off for their foreign domestic helpers each week. This means any foreign domestic workers are entitled for a day off every week, mostly every Sunday. They usually go out and meet other foreign domestic workers who are from similar country. These foreign migrant workers usually spend their time in public places such as malls and parks. In the case of foreign domestic workers from Indonesia, they generally spend their day off to gather in Victoria Park, which is located in the Causeway Bay. Covering an area of 19 hectares, Victoria Park is recognized as the largest park in Hong Kong Island (History of Victoria Park). Every Sunday, IDWs gather in various crowds doing different kinds of activities such as hanging out, sightseeing, gatherings, practicing dance, trading books, and many more. This phenomenon is not new for the people around the neighborhood for this has happened for years. No one quite knows when it started. On a typical day, starting at $9.00 \mathrm{am}$, Victoria Park is gradually full of people. Those who gather in Victoria Park not only come from the Causeway Bay neighborhood but also from other areas of Tung Chung, Wan Chai, and Kowloon. Those places are relatively far from Victoria Park (Purnomo 2014). The gathering usually ends at $5.00 \mathrm{pm}$.

People in Hong Kong can see that a different atmosphere gradually changes the look of Victoria Park each week. IDWs talking in Javanese-local language native to people from Java island-or Bahasa Indonesia are frequently heard in every corner of the park. This regular gathering literally has turned into a cultural practice. As a result, a new title is embedded to this particular park. Local people label Victoria Park as "Kampung Indonesia” (Indonesian Village) 
or "Kampung Jawa" (Javanese Village, since most of the IDWs who work in Hong Kong are from Java island, the Javanese tribe) (Sehari di Victoria Park). People are used to seeing Indonesian cultures such as dances, arts, songs, and food at this particular park. For this reason, it is not surprising to signs written in both in English and Bahasa Indonesia such as "Dilarang merokok" (no smoking) and "Jagalah barang milik anda" (take care of your belongings) to accommodate IDWs as the regular park visitor (Yazid 2010). This is to say that the local government notices that IDWs have formed a specific community whose culture is entitled with Victoria Park.

In the discourse of diaspora, IDWs gathering in Victoria Park is seen to serve as a symbolic place of a home, which enables IDWs to have "a taste of Indonesia". Georgiou in her article argues that "home is the symbolic and real place that becomes a synonym to familiarity, intimacy, security and identity against the unknown, the distant and the large" (Georgiou 7). Her argument helps us to understand how the regular gathering of IDWs and Victoria Park have united in creating "home" for the IDWs. The gathering and interaction in Victoria Park bring a touch of Indonesia in the host country which accommodates the realization of the familiarity, intimacy, security and identity of their homeland within the strangeness of Hong Kong, the new space. This is also considered as the third space, a space of comfort in the midst of chaotic cultural clashes in the host country.

Within their constrained lives as domestic workers, which are always busy with the house chores, IDWs find little personal space in their employers' house. Even though the government has a clear and strict regulation and policy, in practice, the working condition of domestic helpers in Hong Kong is not always good. A study by Hong Kong's Mission of Migrant Workers found that based on interviews with 3000 foreign domestic workers, almost one third had no proper accommodation within their employer's house. Domestic workers barely have their own room. Often times they have to share a room with another member of the household or sleep in the living room, study or the playroom where they have a little privacy (Shadbolt 2014). Such condition is probably experienced by IDWs which can underline how spending their day off in Victoria Park is considered a kind of luxury. Once a week, they can refresh their cramped mind and body by inhaling and enjoying a taste of home in Victoria Park. This park facilitates IDWs to be able to experience how it feels like to be at home, even if it is only for a couple hours. To be able to talk in their mother tongue, eat their home country food and gain the freedom of expression are the things treasured by IDWs. The gathering in Victoria Park undoubtedly shows the dynamic of IDWs life as a migrant. It also actively involves in shaping their diasporic 
identity. Cohen quoted in Georgiou (6) asserts that "diasporic identities are shaped within different spaces in which each different space is attached to a shared sense of belonging and to a sense of longing and shared memory of uprooting." Victoria Park is present as space which is able to bring the sense of belonging and the shared memory of IDWs through the interaction, communal activities, languages and food. Particularly from food, because of "its multisensory capacity (especially through taste and smell, but also sight and touch), food not only evokes past experiences of home as a totality taking migrants back to other places or times but also allows them to recreate the 'sensory landscape of home' in new settings" (Brightwell 78). IDWs' home may be a thousand miles away, but Victoria Park has brought it near.

\section{CONCLUSION}

Migration brings different nuances where the new-migrant - life can be so much different and challenging. Facing this issue, the IDWs in Hong Kong employ negotiations to be able to adjust to their new lives where many lessons gained as they observe the surroundings and live the life in the new place. Portrayed in their memoirs, Insani and Raihan are able to conform to the new habits in the host country. Impediments, of course, are common to happen in the transition period. Therefore, successfully passing this particular period will oftentimes affect much of their migrant experience as domestic workers. The challenges faced and the efforts taken, in a way, provide a picture on how IDWs are marginalized because these women are oftentimes positioned as the subordinate because of the imbalanced power relationship between the employers, the employees and the agents.

Nonetheless, as foreign migrant workers are able to cross the cultural border in the host country, IDWs in Hong Kong are also able to create and secure a new space where they can treasure their "newfound home." Victoria Park emerges as an interstice which becomes the bridge to unite Hong Kong and Indonesia, the host and homeland. This, in a way, highlights IDWs efforts in maintaining the bond with their homeland, for example by having Indonesian food, reading Indonesian books, and magazines, and talking in their mother tongue. A taste of home is indeed available every Sunday in Victoria Park. Between Indonesia and Hong Kong, Victoria Park arises as a comfort space which can ease the pain of being stranger in a Hong Kong because as foreign domestic workers, IDWs usually stay with their employers, which is also a new and strange place for them. In short, Victoria Park as a space accommodates these women to blend both cultures and therefore, creates a new one, the IDWs' culture. 


\section{REFERENCES}

Bappenas. (2015). Jumlah Tenaga Kerja Indonesia Menurut Negara Penempatan. N.p.Nd. 01 Dec. 2015.

Bhabha, H. K. (1994). The Location of Culture. London: Routledge.

Brightwell, M. G. S. L. (2012). A Taste of Home? Food, Identity and Belonging among Brazilians in London, Diss. University of London.

Georgiou, M. (2010). Identity, Space, and the Media: Thinking through Diaspora. Revue Européenne des Migrations Internationales, 26 (1), 17-35. Web. 9 Nov. 2015.

Indonesia: Decent Work for Indonesian Migrant Workers

http://www.refworld.org/pdfid/557fe1bf4.pdf.

Leisure and Cultural Services Department. (2014). History of Victoria Park. Web. 25 Nov. 2015.

Milostivaya, A. et al. (2017). Post-colonial Theory of Homi K. Bhabha: Translator's and Translatologist's Reflections, Advances in Social Science, Education and Humanities Research (ASSEHR), 97: 181-186. Web. 27 October 2019.

Mok, R. (2008). Foreign Domestic Helpers in Hong Kong: Towards Equality of Rights, Queensland Law Student Review, 1(2), 101-16. Web. 10 Nov. 2015.

Purnomo, S. H. (2014). Taman Victoria Tempat Melepas Rindu BMI Hong Kong, Antara Jatim.com. N.p., 4 Apr. Web. 29 Oct. 2015.

Shadbolt, P. (2014). Indonesian Migrant Worker Tells of Abuse as Thousands Protest in Hong Kong, CNN.com. N.p., 21 Jan. Web. 4 Dec. 2015.

Tonder, C. L. V \& Soontiens, W. (2017). Migrant Acculturation and the Work Place, Procedia Social and Behavioral Sciences, 143, 1041-1047. Web 27 October 2019.

VOA Islam. (2011). Sehari di Victoria Park, "Kampung Jawa"nya TKW di Hong Kong. Web. 09 Nov. 2015.

Yazid, M. (2010). Freedom in Hong Kong, The Jakarta Post. N.p., 14 Sept. Web. 2 Nov. 2015. 